\title{
HIV-related knowledge level among Indonesian women between 15 years and 49 years of age
}

Ferry Efendi ${ }^{1,4}$, Emha Rafi Pratama ${ }^{1}$, Setho Hadisuyatmana ${ }^{1,4}$, Retno Indarwati ${ }^{1}$, Linlin Lindayani ${ }^{2}$, Angeline Bushy ${ }^{3}$

1. Faculty of Nursing, Universitas Airlangga, Surabaya, Indonesia.

2. Sekolah Tinggi Ilmu Keperawatan PPNI Jawa Barat, Bandung, Indonesia.

3. College of Nursing, University of Central Florida, USA.

4. School of Nursing and Midwifery, La Trobe University Australia.

\begin{abstract}
Background: Women are a highly vulnerable population for HIV-infection, influenced by biological, cultural, social and economic factors. Inadequate knowledge about the risk for exposure to HIV will impact the prevention and treatment of HIV.

Objectives: The aim of this study was to examine HIV-related knowledge among women in Indonesia and the associated demographic determinants that influence their access to accurate HIV-related information.

Methods: This was a secondary analysis of the Indonesia Demographic and Health Survey in 2012. Level of HIV-related knowledge was determined by analyzing nine items on the 2012 IDHS instrument.

Results: The percentage of women in Indonesia between the ages of 15 and 49 years of age, more than half (53.6\%) had high score of HIV-related knowledge. The results from logistic regression showed that women aged 30-34 years old had 2.2 times higher knowledge level about HIV compared to older women. Married women, living in rural area, with a lower level of education, reported to have limited or no access to HIV related information; thus, had a correspondingly lower knowledge level of HIV.

Conclusion: Study findings underscore the lack of knowledge-level among Indonesian women about HIV, especially the prevention, transmission, and prevention mother to child transmission (PMCT).
\end{abstract}

Keywords: HIV, Knowledge, prevention, women, demographic health survey.

DOI: https://dx.doi.org/10.4314/ahs.v20i1.13

Cite as: Efendi F, Pratama ER, Hadisuyatmana S, Indarwati R, Lindayani L, Bushy A. HIV-related knowledge level among Indonesian women between 15 years and 49 years of age. Afri Health Sci. 2020;20(1):83-90. bttps:// dx.doi.org/10.4314/abs.v20i1.13

\section{Introduction}

Human immunodeficiency virus (HIV) in Indonesia is a serious public health concern, and the associated social problems remain a priority for action. Indonesia is ranked second highest number of people (males and women) living with HIV (PLWH) in the South-East Asia Region (SEAR), and the rate increased significantly annually ranging from 5,846 in 2004 to 242.699 in $2017^{1}$. The HIV prevalence among Women also continues to increase every year, accounting for $32 \%$ of total PLWH in $2017^{2,3}$.

\section{Corresponding author:}

Ferry Efendi,

Faculty of Nursing, Universitas Airlangga,

Surabaya, Indonesia

Jl. Mulyorejo Kampus C Unair, Indonesia

$+6281331533805(\mathrm{M})$

+62315913257(O)

Email: ferry-e@fkp.unair.ac.id
Although the number of new HIV infection decreased by $19 \%$ from 2014 to 2017, the risk of HIV transmission remains high ${ }^{3}$. Associated with lack of knowledge and the serious stigma in HIV, individuals in the highest risk groups tend to have limited access to relevant HIV education and social services. In turn, this probably results in the underreporting of HIV in those medically underserved and more remote regions of the nation ${ }^{1,4,5}$. Therefore, the knowledge level of HIV is a critical factor in HIV prevention 6 .

Women are a highly vulnerable population for HIV-infection, influenced by biological, cultural, social and economic factors ${ }^{1,5}$. The risk of HIV in women is estimated to be from 2 to 4 times greater than for male due to their reproductive and genital anaomic structures which facilitates HIV transmission with sexual intercourse ${ }^{7}$. Culturally, gender inequality, male dominance, and stigma exacerbate the Women vulnerability further increasing their vulnerability for HIV exposure ${ }^{8}$. A previous study 
in Indonesia reported that most Indonesia women have been involved in deciding their health care but are relegated less power in social and economic decision making ${ }^{2,9}$. Furthermore, for a married woman who is pregnant with HIV, there are long-term consequences for her children such as her child has the potential to be infected by HIV if did not do prevention in advance.

Inadequate knowledge about the risk of exposure to HIV will also impact the prevention and treatment for PLWH, perpetuated by the stigma and the discrimination of being HIV positive ${ }^{10}$. A previous study conducted in Nigeria found that only $24 \%$ of women had comprehensive knowledge about transmission of $\mathrm{HIV}^{11}$. Previous studies conducted in 137 countries reported the gender gap in the knowledge level of HIV decreased and knowledge about HIV prevention was even lower among women ${ }^{12}$. A study conducted in Uganda and Bangladesh indicated that women's knowledge of HIV in both countries was unevenly distributed with disparities found based on economic status and education level ${ }^{13,14}$. Furthermore, in Sub-Saharan Africa found that accurate and comprehensive information about HIV would reduce the risk of HIV infection $^{15}$. Factors associated with HIV-related knowledge in Indonesia included age, gender, and education background and place of residence has been previously reported ${ }^{16}$. However, there is a paucity of information focusing women's knowledge level about HIV prevention and management associated with the increased emphasis on exposure to HIV-related information. The purpose of this study was to examine HIV-related knowledge among Women in Indonesia and the associated demographic determinants that influence their access to accurate HIV-related information.

\section{Methods}

Secondary data from the 2012 Indonesian Demographic Data Survey (IDHS). IDHS were analyzed. This survey is a component of the International Demographic and Health Survey (DHS) program. The 2012 IDHS was carried out by the Central Statistics Agency (BPS) in collaboration with the National Population and Family Planning Board (BKKBN) and the Ministry of Health. The International Inner City Fund (ICF) provided technical assistance through the MEASURE DHS project, funded by the United States Agency for International Development (USAID). The 2012 IDHS was conducted in 33 provinc- es from May to August 2012. Women between the ages of 15 to 49 years old were included in the analysis, using stratification and multistage random sampling techniques. The 2012 IDHS included 43,852 households ${ }^{17}$; for this study, data were analyzed for $\mathrm{N}=45,067$ ranging from 15 yers to 49 years of age.

The 2012 IDHS obtained ethical permission from the National Institute of Health Research and Development, Indonesian Ministry of Health. Respondents provided written informed consent which is securely maintained by the Indonesian Ministry of Health. Permission to use data for this study was obtained from ICF InternationalDHS10 program. All respondents' identities were deleted from the secondary data that were analyzed for this study.

The knowledge of HIV was assessed using the 2012 IDHS questionnaire for women, which consisted of nine items (yes or no responses), focusing on the transmission of HIV, [personal] prevention, prevention of mother-tochild transmission (PMTCT). Knowledge-level of HIV was categorized as "good enough" or "lack of knowledge."

Determinants (factors) of women knowledge level about HIV included demographics, place of residence (geographic area, i.e., urban, rural), socioeconomic, and access to information. Demographic factors were age (15-19 years, $20-24$ years, $25-29$ years, $30-34$ years, $35-39$ years, 40-44 years, 45-49 years, age was classified based on Indonesian demographic data classification) and marital status was defined based on the Indonesian law (unmarried, married). Education was determined by formal years of education (not at all, primary, secondary, higher education) and economic status by measure monthly income (lowest, lower middle, middle, upper middle, higher); access to information such as newspaper, radio and television (no. yes - at least once each week).

All data were analyzed using IBM SPSS version 22.0 for Windows 10.

Univariate analysis and Chi-square test were used to determine the relationship among demographic variables, place of residence (geographic area), socio-economic factors and access to information with knowledge-level of HIV. Further analysis was undertaken to determine significant factors associated with knowledge-level of HIV using a logistic regression model. 


\section{Results}

Table 1 summarizes demographic characteristics of all Indonesian women ranging in age from 15 years to 49 years of age. Of these, the majority were married
(76.5\%); more than half had completed secondary education $(52 \%)$ and were lower-mid socioeconomic status (20.1\%). More than half had access to a newspaper and or radio at least once weekly, but almost all had access to televisions $(95.2 \%)$.

Table 1. Demographic characteristics of Indonesian women $(\mathrm{N}=45,067)$

\begin{tabular}{|c|c|c|}
\hline \multicolumn{2}{|l|}{ Variables } & $\%$ \\
\hline \multicolumn{3}{|l|}{ Age in years } \\
\hline $15-19$ & $\mathrm{n}=7123$ & 15.8 \\
\hline $20-24$ & $\mathrm{n}=6519$ & 14.5 \\
\hline $25-29$ & $\mathrm{n}=7070$ & 15.7 \\
\hline $30-34$ & $\mathrm{n}=6879$ & 15.3 \\
\hline $35-39$ & 6694 & 14.8 \\
\hline $40-44$ & 5826 & 12.9 \\
\hline $45-49$ & 4986 & 11.1 \\
\hline \multicolumn{3}{|l|}{ Marital status } \\
\hline \multirow{2}{*}{$\begin{array}{l}\text { Unmarried } \\
\text { (never married/divorced) } \\
\text { Married }\end{array}$} & 10618 & 23.5 \\
\hline & 34779 & 76.5 \\
\hline \multicolumn{3}{|l|}{ Place of residence } \\
\hline (Geographic) & 22615 & 50.1 \\
\hline $\begin{array}{l}\text { Urban } \\
\text { Rural }\end{array}$ & 22482 & 49.9 \\
\hline \multicolumn{3}{|l|}{$\begin{array}{l}\text { Education level (years of } \\
\text { formal education) }\end{array}$} \\
\hline Not at all & 1606 & 3.6 \\
\hline Not at all & 13594 & 30.1 \\
\hline Primary & 23461 & 52.0 \\
\hline $\begin{array}{l}\text { Secondary } \\
\text { Higher }\end{array}$ & 6436 & 14.3 \\
\hline \multicolumn{3}{|l|}{ Economic status (monthly } \\
\hline income) & 10527 & 23.3 \\
\hline Lowest & 9065 & 20.1 \\
\hline Lower middle & 8579 & 19.0 \\
\hline Middle & 8379 & 18.6 \\
\hline Upper middle & 8547 & 19.0 \\
\hline \\
\hline & & \\
\hline No & 21551 & 47.8 \\
\hline \multicolumn{3}{|l|}{ At least once a week } \\
\hline \multicolumn{3}{|l|}{ Access to radio } \\
\hline No & 20993 & 46.6 \\
\hline At least once a week & 24104 & 53.4 \\
\hline \multicolumn{3}{|l|}{ Access to TV } \\
\hline No & 2146 & 4.8 \\
\hline At least once a week & 42951 & 95.2 \\
\hline
\end{tabular}

HIV-related knowledge level among Indonesian women is highlighted in Table 2. With respect to understanding the HIV mode of transmission, most women gave a correct response. Specifically, transmission of HIV is not through mosquitos' bites (75.1\%); and, HIV can be transmitted by sharing needle $(69.7 \%)$ and cannot be transmitted by sharing food with PLWH (68.9\%). Regarding the PMTCT-related questions, about half responded correctly for the prevention strategy of having a monoga- mous partner (56\%); people who are healthy can have HIV (58.9\%). In contrast, $57.1 \%$ of the women did not correctly respond to the item related to male condom use for HIV prevention during sexual intercourse. In bivariate analysis, there were significant associations between the Women's age, marital status, Place of residence (geographic area -urban/rural), socioeconomic status, and access to information (newspaper, radio, and television) with their knowledge level of HIV $(p<0.05)$ (Table 3). 
Table 2. Percentage of Indonesian women responding to HIV survey $(\mathrm{N}=45,067)$

\begin{tabular}{ll}
\hline Questions/Items & Correct Response (\%) \\
\hline Always use a condom during sexual intercourse & 42.9 \\
Only have one partner & 56.0 \\
Can be infected with HIV by mosquito bites & 75.1 \\
Can be infected with HIV from sharing food with PLWHA & 68.6 \\
People who are healthy can have HIV & 58.9 \\
HIV is transmitted during pregnancy & 63.4 \\
HIV is transmitted during labor & 55.6 \\
HIV is transmitted through ASI & 61.5 \\
Can be infected with HIV by sharing needles & 69.7 \\
\hline
\end{tabular}

Table 3. Determinants of Indonesian womens' HIV knowledge level $(\mathrm{N}=45,067)$

\begin{tabular}{|c|c|c|c|c|}
\hline \multirow{2}{*}{ Variables } & \multicolumn{3}{|c|}{ HIV Knowledge (\%) } & \multirow[t]{2}{*}{$X^{2}$} \\
\hline & $<$ & $=$ & $>$ & \\
\hline \multicolumn{5}{|l|}{ Age in years } \\
\hline $15-19$ & 18.3 & 25.7 & 56.0 & \multirow[t]{7}{*}{$1444.40^{*}$} \\
\hline $20-24$ & 20.7 & 22.3 & 57.0 & \\
\hline $25-29$ & 22.1 & 21.0 & 56.8 & \\
\hline $30-34$ & 22.7 & 20.0 & 57.2 & \\
\hline $35-39$ & 27.4 & 18.5 & 54.2 & \\
\hline $40-44$ & 33.0 & 17.9 & 49.1 & \\
\hline $45-49$ & 43.7 & 15.5 & 40.9 & \\
\hline \multicolumn{5}{|l|}{ Marital status } \\
\hline Unmarried & 14.3 & 24.6 & 61.1 & \multirow[t]{2}{*}{$1000.34 *$} \\
\hline (never married/divorced) & 29.6 & 19.1 & 51.3 & \\
\hline \multicolumn{5}{|l|}{ Married } \\
\hline Place of & & & & \multirow{3}{*}{$4110.55^{*}$} \\
\hline (Geographic) & 13.2 & 21.0 & 65.8 & \\
\hline Urban & 38.8 & 19.8 & 41.4 & \\
\hline \multicolumn{5}{|l|}{ Rural } \\
\hline Education level (years of & & & & \multirow{5}{*}{$12578.3^{*}$} \\
\hline formal education) & 85.8 & 6.4 & 7.8 & \\
\hline Not at all & 52.2 & 18.6 & 29.3 & \\
\hline Primary & 13.5 & 23.6 & 63.0 & \\
\hline Secondary & 1.3 & 16.3 & 82.3 & \\
\hline \multicolumn{5}{|l|}{ Higher } \\
\hline Economic status (monthly & & & & \multirow{5}{*}{$7578.87^{*}$} \\
\hline $\begin{array}{l}\text { income) } \\
\text { Lowest }\end{array}$ & $\begin{array}{l}53.8 \\
30.6\end{array}$ & $\begin{array}{l}17.6 \\
22.7\end{array}$ & $\begin{array}{l}20.0 \\
46.7\end{array}$ & \\
\hline Lower middle & 19.5 & 22.7 & 57.8 & \\
\hline Middle & 12.4 & 20.8 & 66.7 & \\
\hline Upper middle & 6.6 & 18.8 & 74.6 & \\
\hline \multicolumn{5}{|l|}{ Higher } \\
\hline $\begin{array}{l}\text { Access to written media } \\
\text { (newspapers / magazines) }\end{array}$ & 41.3 & 20.6 & 38.2 & \multirow[t]{2}{*}{$5541.73 *$} \\
\hline No & 12.0 & 20.3 & 67.7 & \\
\hline \multicolumn{5}{|l|}{ At least once a week } \\
\hline Access to radio & & & & \\
\hline No & 34.3 & 20.6 & 44.9 & \multirow{2}{*}{$1637.42 *$} \\
\hline At least once a week & 18.6 & 20.2 & 61.2 & \\
\hline \multicolumn{5}{|l|}{ Access to TV } \\
\hline No & 64.1 & 14.4 & 21.5 & \multirow[t]{2}{*}{$1732.19^{*}$} \\
\hline At least once a week & 24.1 & 20.7 & 55.2 & \\
\hline
\end{tabular}


The logistic regression analysis found that age, marital status, place of residence, education level, socioeconomic status, and access to information was significantly associated with knowledge-level of HIV (Table 4). Indonesian women between 30 to 34 years of age $(\mathrm{OR}=2.13$, $95 \% \mathrm{CI}=1.88-2.40)$, were not married $(\mathrm{OR}=1.12,95 \%$
$\mathrm{CI}=1.01-1.26)$, and living in the urban area $(\mathrm{OR}=1.62$, $95 \% \mathrm{CI}=1.52-1.74)$ contributed more notably to the modest knowledge level about HIV. Furthermore, women between 30 to 34 years of age $(\mathrm{OR}=2.21,95 \%$ $\mathrm{CI}=1.98-2.45)$ and living in the urban area $(\mathrm{OR}=1.84$, $95 \% \mathrm{CI}=1.73-1.95)$ were found to be stronger factors associated with higher level of HIV-related knowledge.

Table 4. Logistic regression analysis of Indonesian women HIV knowledge level (adjusted and unadjusted odds ratios)

\begin{tabular}{|c|c|c|c|c|c|c|}
\hline variables & OR & $95 \% \mathrm{CI}$ & $\begin{array}{l}\mathrm{p}- \\
\text { value }\end{array}$ & OR & $95 \% \mathrm{CI}$ & p-value \\
\hline \multicolumn{7}{|l|}{ Age in year } \\
\hline $15-19$ & $\begin{array}{l}1.73(1.49- \\
2.01)\end{array}$ & $1.49-2.01$ & 0.000 & 1.50 & $1.31-1.72$ & 0.000 \\
\hline $20-24$ & 1.82 & $1.60-2.07$ & 0.000 & 1.60 & $1.43-1.79$ & 0.000 \\
\hline $25-29$ & 1.99 & $1.76-2.25$ & 0.000 & 1.90 & $1.70-2.11$ & 0.000 \\
\hline $30-34$ & 2.13 & $1.88-2.40$ & 0.000 & 2.21 & $1.98-2.45$ & 0.000 \\
\hline $35-39$ & 1.67 & $1.84-1.88$ & 0.000 & 1.82 & $1.64-2.02$ & 0.000 \\
\hline $40-44$ & 1.37 & $1.22-1.55$ & 0.000 & 1.39 & $1.25-1.55$ & 0.000 \\
\hline $45-49$ & Ref. & & & & & \\
\hline Marital status & Married & & & & & \\
\hline $\begin{array}{l}\text { Unmarried } \\
\text { (never married/divorced) }\end{array}$ & $\begin{array}{l}1.12 \\
\text { Ref. }\end{array}$ & $1.01-1.26$ & 0.040 & 0.88 & $0.80-0.98$ & 0.021 \\
\hline $\begin{array}{l}\text { Place of residence } \\
\text { (Geographic) }\end{array}$ & & & & & & \\
\hline Urban & 1.62 & $1.52-1.74$ & 0.000 & 1.84 & $1.73-1.95$ & 0.000 \\
\hline Rural & Ref. & & & & & \\
\hline \multicolumn{7}{|c|}{$\begin{array}{l}\text { Education level (years of } \\
\text { formal education }\end{array}$} \\
\hline Not at all & 0.02 & $0.02-0.03$ & 0.000 & 0.01 & $\begin{array}{l}0.006 \\
0.011\end{array}$ & 0.000 \\
\hline Primary & 0.07 & $0.06-0.09$ & 0.000 & 0.03 & $0.02-0.04$ & 0.000 \\
\hline Secondary & 0.23 & $0.18-0.28$ & 0.000 & 0.14 & $0.11-0.18$ & 0.000 \\
\hline Higher & Ref. & & & & & \\
\hline \multicolumn{7}{|c|}{$\begin{array}{l}\text { Economic status (monthly } \\
\text { income) }\end{array}$} \\
\hline Lowest & 0.32 & $0.29-0.37$ & 0.000 & 0.21 & $0.19-0.23$ & 0.000 \\
\hline Lower middle & 0.56 & $0.50-0.63$ & 0.000 & 0.40 & $0.36-0.45$ & 0.000 \\
\hline Middle & 0.71 & $0.63-0.81$ & 0.000 & 0.59 & $0.52-0.66$ & 0.000 \\
\hline Upper middle & 0.83 & $0.73-0.85$ & 0.005 & 0.77 & $0.69-0.87$ & 0.000 \\
\hline Higher & Ref. & & & & & \\
\hline \multicolumn{7}{|c|}{$\begin{array}{l}\text { Access to written media } \\
\text { (newspapers / magazines) }\end{array}$} \\
\hline None & 0.67 & $0.62-0.72$ & 0.000 & 0.49 & $0.46-0.52$ & 0.000 \\
\hline $\begin{array}{l}\text { At least once a week } \\
\text { Access to Radio }\end{array}$ & Ref. & & & & & \\
\hline None & 0.92 & $0.86-0.97$ & 0.008 & 0.80 & $0.75-0.85$ & 0.000 \\
\hline $\begin{array}{l}\text { At least once a week } \\
\text { Access to TV }\end{array}$ & Ref. & & & & & \\
\hline None & 0.78 & $0.67-0.89$ & 0.000 & 0.71 & $0.62-0.80$ & 0.000 \\
\hline At least once a week & Ref. & & & & & \\
\hline
\end{tabular}

\section{Discussion}

The findings in the analysis of secondary data from the 2012 IDHS survey showed that more than half of all Indonesian women have inaccurate or very limited HIV-related awareness and knowledge. A previous study conducted in Nigeria reported a majority of women had a higher awareness of HIV, but only 24\% had comprehensive knowledge about transmission of $\mathrm{HIV}^{11}$. Insufficient knowledge of HIV prevention, HIV transmission, and prevention mother to child transmission (PMTCT) increases vulnerability to HIV infection in women ${ }^{18}$. Vulnerable groups in general, women in particular, should have 
the same access to health care services and the self-determination to participate in their health care decision making. Accurate knowledge about HIV prevention reduces one's risk for HIV exposure and subsequent infection. A study conducted in Sub-Saharan Africa found that accurate and comprehensive information, increased knowledge-level about HIV prevention significantly reduce the risk of getting infected by the HIV ${ }^{15}$. This findings of this study found there is a serious need for Indonesian women from 15 to 49 years of age need more information about HIV transmission and prevention ${ }^{10}$. Designing health education program about HIV and spread out the information widely is urgently needed to reduce HIV transmission among women in Indonesia.

This study showed that Indonesia women from 30 to 34 years of age had better knowledge compared to others aged groups. This finding may be associated with cultural factors, their access to information, and lower educational levels. For example, if they have high education background and therefore can accurately read and understand written information like newspapers, magazines etc, or they have a high economic status that they can afford to buy a television set and watch any educational programme that is aired. Previous study conducted in Bangladesh suggested that as the person matures, the individual is more likely to be exposed to additional accurate health-related information, which should also increase knowledge level and awareness ${ }^{13}$. A similar study conducted among women in Kenya, Ethiopia, and Burundi found that women aged 30 to 34 years old had better knowledge of HIV compare to younger women aged 19. However, our study found that women 39 years of age and older had lower knowledge of HIV. This finding needs to be further investigated to determine factors that contribute to this finding.

Unmarried women had a lower HIV related knowledge level compared to married counterparts. In the pre-dominate Indonesian culture, discussed sexual health or responsible sexual activity are taboo topics, especially for single and unmarried women. Thus, they are less likely to discuss sexual issues particularly topics related to HIV transmission and prevention. Therefore, unmarried women may not have this information source. A similar with a study conducted in Kenya reported that unmarried women had a higher knowledge of HIV due to they need to secure everything by them self ${ }^{20}$. In contrast to the previous study, found that married women had a higher knowledge of HIV. The different results in this study might be due to different demographic characteristics such as educational background ${ }^{21}$ and media exposure. Furthermore, researchers argue that married women may have an opportunity to gain information from their partner(s) such as responsible sexual behaviors that address risk factors for HIV exposure ${ }^{22}$.

These findings highlight inequality in infrastructure development to help people easily able to access information. Women with more formal education also had a higher HIV knowledge level. However, the majority of Indonesian women have completed less than a secondary level of education. Years of education significantly influenced women HIV knowledge level ${ }^{13,22}$. More years of formal education is essential for creating awareness, hence knowledge level with exposure to relevant information, in this case, HIV transmission and prevention.

Economic status also was found to be is significantly related to Indonesian women HIV knowledge level. Consistent with a study conducted in Bangladesh, but different from research conducted in Kenya which reported no significant relationship between economic status and knowledge about $\mathrm{HIV}^{20,23}$. Higher economic status is associated with better ease of access to HIV related information and a better opportunity to pursue a higher education level. Women in better economic situations tend to be more aware of their health status and better prepared to make decisions about health behaviors.

This study found Indonesian women residing in urban areas had 1.62 times great knowledgeable level than rural counterparts. In Indonesia access to media sources, both electronic and written materials, often is limited or perhaps even inaccessible in many more remote and rural areas ${ }^{24}$. Another study in Indonesia emphasized that people who lived in the rural area more prefer to rely on cultural traditions and beliefs about health, sexual activity, and reproduction. Moreover, community leaders often view HIV as a "curse" for the individual, family and even the community ${ }^{25}$.

This finding is consistent with other researchers in Bangladesh and Sudan ${ }^{23,26}$. Urban residence generally offers greater opportunity to access media of various types; and, perhaps better exposure to HIV-related information. Transparency regarding the pevalence of HIV in Indonesia, encouraging open discussions and improving access 
to information are all essential to facilitate information access for Indonesian women, rural and urban alike, to learn about HIV transmission, prevention, and resources. Some limitation of our study should be acknowledged. First, our study was based on secondary of the 2012 IDHS survey may not reflect the current HIV-related knowledge level among Women in Indonesia accurately. Second, the instrument measured HIV-related knowledge level not using validate instrument which may be biased. However, our study was a national survey with a large sample size that allowed to generalize to all women aged 15-49 years old in Indonesia. A more comprehensive assessment of HIV-related knowledge level is needed to understand the impact of socioeconomic and cultural factors.

\section{Conclusion}

This study set out to determine that Indonesian women who were aged 30 to 34 years old, unmarried, living in urban area, higher education and economic status showed better knowledge of HIV compared to older age, married and living in rural area. Our findings underscore the needs for optimizing existing facilities and infrastructure in the rural area to provide comprehensive knowledge about HIV base on the local needs. Furthermore, policy maker need to design a wide health education program targeted to women who were uneducated, poor, unmarried and lived in rural area using an innovative strategy.

\section{Declaration of conflict of interest}

The author(s) declared no potential conflicts of interest with respect to the research, authorship, and/or publication of this article.

\section{References}

1. Indonesian Ministry of Health. Situasi Penyakit HIV AIDS di Indonesia. Pus Data dan Informasi 2016.

2. UNAIDS. Women and girls SNAPSHOT. 2016.

3. Indonesian Ministry of Health. Faktor Risiko Penularan HIV/AIDS pada Laki-Laki dengan Orientasi Seks Heteroseksual 'Laporan Perkemb HIV/AIDS 7 Penyakit Menular Seksual Triwulan I Tahun 2017’. 2017.

4. Lindayani L, Ibrahim K, Wang JD, et al. Independent and synergistic effects of self- and public stigmas on quality of life of $\mathrm{HIV}$-infected persons. AIDS Care 2018; 30: 706-713 PubMed . 2017/11/09. DOI: 10.1080/09540121.2017.1396282.
5. Kobeissi L, El Kak FH, Khawaja M, et al. HIV/ AIDS-related knowledge and its association with socioeconomic status among women: results of Lebanese Survey for Family Health (PAPFAM) 2004. Asia Pac J Public Health 2015; 27: NP734-745. 2011/12/22. DOI: 10.1177/1010539511431299.

6. Sudha RT, Vijay DT and Lakshmi V. Awareness, attitudes, and beliefs of the general public towards HIV / AIDS in Hyderabad, a capital city from South India. Indian J Med Sci 2005; 59: 307-316. 2005/08/03.

7. Azza A. The Woman Burden of HIV/AIDS Patient in Gender Perspective. Jurnal Ners 2010; 5: 118-126.

8. WHO. HIV/AIDS in the South-East Asia Region: Progress Report. 2011.

9. Kurniati A, Chen CM, Efendi F, et al. Factors influencing Indonesian women's use of maternal health care services. Health Care Women Int 2018; 39: 3-18. 2017/10/21. DOI: 10.1080/07399332.2017.1393077.

10. Iswanto L. Pengetahuan Perempuan Indonesia Tentang HIV/AIDS. Populasi 2011; 22: 68-75. DOI: https:// doi.org/10.22146/jp27030.

11. Yaya S, Ghose B, Udenigwe O, et al. Knowledge and attitude of HIV/AIDS among women in Nigeria: a cross-sectional study. EurJ Public Health 2018 2018/07/28. DOI: 10.1093/eurpub/cky131.

12. Hossain M MK, Sidik SM, Shahar HK, Islam R. Knowledge and Awareness About STDs Among Women in Bangladesh. BMC Public Health 2014; 14: 775.

13. Yaya S, Bishwajit G, Danhoundo G, et al. Trends and determinants of HIV/AIDS knowledge among women in Bangladesh. BMC Public Health 2016; 16: 812. 2016 PubMed /08/19. DOI: 10.1186/s12889-016-3512-0.

14. Ankunda D AJ. Determinant of comprehensive knowledge of HIV/AIDS among women of the reproductive age (15-49) in Uganda. Int J Community Med Public Heal 2017; 4: 3530-3535 PubMed. DOI: doi:10.18203/23946040.ijcmph20174215.

15. Wang W AS, Wang S. HIV-Related Knowlege and Behaviors among People Living with HIV in Eight High HIV Prevalence Countries in Sub-Saharan Africa. 2012. DOI: doi:10.13140/RG.2.1.2355.1524.

16. Oktarina HF, Budisuari MA. Hubungan Antara Karakteristik Responden, Keadaan Wilayah dengan Pengetahuan, Sikap Terhadap HIV/AIDS pada Masyarakat Indonesia. Bul Penelit Sist Kesehat 2009; 124: 362-369.

17. BPS B. Survei Demografi dan Kesehatan Indonesia 2012. 2013. DOI: doi:10.1111/j.1471-0528.2007.01580.x. 
18. Duarte MT, Parada CM and Souza Ldo R. Vulnerability of women living with HIV/AIDS. Rev Lat Am Enfermagem 2014; 22: 68-75. 2014/02/21. DOI: 10.1590/01041169.2837.2377.

19. Teshome R YW, Habte E, Mohamedkassm N. Trends and Determinants of Comprehensive Knowledge of HIV Among Adolescents and Young Adults in Nigeria: 2003-2013. J AIDS Clin Res 2016; 07: 1-8 PubMed . DOI: doi:10.4172/2155-6113.1000559.

20. Ochako R, Ulwodi D, Njagi P, et al. Trends and determinants of Comprehensive HIV and AIDS knowledge among urban young women in Kenya. A AIDS Res Ther 2011; 8: 11. 2011/03/08. DOI: 10.1186/1742-6405-8-11. 21. Oginni AB AS, Ahonsi BA. Trends and Determinants of Comprehensive Knowledge of HIV Among Adolescents and Young Adults in Nigeria: 2003-2013. Afr J Reprod Health 2017; 21: 26-34 PubMed.
22. HD R. Faktor-faktor yang berhubungan dengan pengetahuan pencegahan dan penularan HIV/AIDS penduduk umur $>15$ tahun berdasarkan data riset kesehatan dasar tahun 2010. Thesis 2012.

23. Sheikh MT UM, Khan JR. A Comprehensive Analysis of Trends and Determinants of HIV/AIDS Knowledge Among the Bangladeshi Women Based on Bangladesh Demographic and Health Surveys, ,2007-2014. Arch Public Heal; 75: 59.

24. BS M. HIV/AIDS Knowledge, Attitudes and Practices Among Women in South Sudan Based on Multiple Indicator Cluster Survey. 2017; 31: 65-74. DOI: doi:10.14456/ jhr.2017.69.

25. VM R. Perilaku Pemenuhan dan Penyebaran Informasi Publik Bagi Masyarakat Kota dan Desa. J Penelit Komun 2017; 20: 91-106. DOI: 10.20422/jpk.v20i1.146.

26. Sapi P LS. Pandangan Masyarakat Terhadap Penyakit HIV/AIDS. 2010. 